\title{
Comparison of seed dormancy breaking of Eusideroxylon zwageri from Bali and Kalimantan soaked with sodium nitrophenolate growth regulator
}

\author{
JHON HARDY PURBA ${ }^{1, \boldsymbol{v}}$, NANANG SASMITA ${ }^{2}$, LIRIS LIS KOMARA ${ }^{2}$, NOH NESIMNASI ${ }^{3}$ \\ ${ }^{1}$ Faculty of Agriculture, Universitas Panji Sakti. Jl. Bisma No. 22, Banjar Tegal, Singaraja, Buleleng 81125, Bali, Indonesia \\ vemail: jhonhardy@yahoo.com \\ ${ }^{2}$ Faculty of Forestry, Sekolah Tinggi Pertanian. Jl. Soekarno Hatta No. 1, Sangatta Utara, East Kutai 75611, East Kalimantan, Indonesia \\ ${ }^{3}$ Faculty of Agriculture, Universitas Udayana. Jl. P.B. Sudirman, Denpasar 80114, Bali, Indonesia
}

Manuscript received: 20 May 2019. Revision accepted: 3 August 2019.

\begin{abstract}
Purba JH, Sasmita N, Komara LL, Nesimnasi N. 2019. Comparison of seed dormancy breaking of Eusideroxylon zwageri from Bali and Kalimantan soaked with sodium nitrophenolate growth regulator. Nusantara Bioscience 11: 146-152. Eusideroxylon zwageri is a very strong and durable wood, which can be used as building materials. This wood plant needs 6-12 months to germinate, but it can be shorted with special treatment (e.g. cracking). Therefore, it is important to conduct research to stimulate E. zwageri seed germination using sodium nitrophenolate growth regulator. The purpose of this study was to analyze the comparison of the fastest time to breaking E. zwageri seed dormancy from the Bali and Kalimantan island. The research method was factorial randomized block design, using the $\mathrm{X}$ factor (soaking time) and $\mathrm{Y}$ factor (sodium nitrophenolate growth regulator). There were four soaking time treatment, i.e., immersed (soaked in a really short time), 12 and 24 hours soaking time. While the Y factor was the concentration of sodium nitrophenolate with 4 treatments: without sodium nitrophenolate solution or $0 \mathrm{~mL}$ (control), soaked in a $1 \mathrm{~mL} / \mathrm{L}$ of water, 2 $\mathrm{mL} / \mathrm{L}$ of water and $3 \mathrm{~mL} / \mathrm{L}$ of water solution. The study results showed the best treatment of $E$. zwageri seeds germination speed was soaked for 24 hours, and by giving 0,3\% sodium nitrophenolate concentration, while the interactions of both showed no significant effect. The soaked time treatment, sodium nitrophenolate concentration, and the interaction of both show no significant effect on germination percentage. The breaking of E. zwageri seed dormancy from Kalimantan has a shorter time to germinate than E. zwageri seeds from Bali.
\end{abstract}

Keywords: Eusideroxylon zwageri, germination, seeds, sodium nitrophenolate growth regulator

\section{INTRODUCTION}

Indonesia has some of the extensive tropical rainforests and biodiversity in the world (MacKinon 2005). One of the riches possessed by tropical rainforests is Ironwood (Eusideroxylon zwageri). Ironwood is one of the trees with a scattered life type. In lowland forests, this tree can grow 400 meters above sea level. Sometimes ironwood trees form a pure, grouped and scattered stands and it's also found in secondary forests. E. zwageri is a tree of the family Lauraceae. The name Ulin (Ironwood) (E. zwageri) is the original name of various regions in Kalimantan, while in abroad it is known as Borneo Ironwood (UK and USA), Billian (Spanish), Tabulan (Sabah), Sakian (Philippines), Ku-an-tin (Hong Kong), Legno fero del Borneo (Italy), Borneojarntra (Sweden) and in Germany called Borneo Eisenholz. Taxonomically, E. zwageri trees can be classified as Plantae (Kingdom), Spermatophyta (Division), Angiospermae (Subdevisi), Monokotyledon (Class), Ramales (Order), Lauraceae (Family), Eusideroxylon (Genus) and species named E. zwageri (Martawijaya et al. 1989).

East Kalimantan is the largest area of E. zwageri spread compared to other regions. Another type of $E$. zwageri which can be found in West Kalimantan and East
Kalimantan is Eusideroxylon malagangai, or also called as onglen wood or malaga wood which can float in water. Eusideroxylon malagangai is found in low soils of tropical rainforests in Sarawak Malaysia with alluvial soils characteristic. Since seed germination, E. zwageri needs a light. E. zwageri trees are semi-tolerant plants, especially when they are young or seedlings. At sapling level, it requires sufficient light to grow well, but adult $E$. zwageri can withstand to shade.

Along with the rapid increasing population growth, $E$. zwageri demand for the development is increasing. This has increased the exploitation of E. zwageri in natural forests from year to year, so the existence of $E$. zwageri trees has dropped dramatically, that's why its existence is protected by law. Given the scarcity of E. zwageri trees, an effort to save the existence of E. zwageri trees is necessary. One of the salvages that need to be carried out is propagation both vegetatively and generatively. In general, it usually comes from seeds, besides E. zwageri can also develop naturally, namely with sprouted pups.

Today there are many studies conducted from various aspects, one of which is by using growth regulators such as Rootone F, IBA, and Sodium nitrophenolate. But there were also those who tried using IBA hormones and fertilizers. This accelerated germination method was 
applied at the Samboja East Kalimantan Wana research center. In general, germination of E. zwageri seeds is very slow because it has a very hard seed coat that makes it difficult to absorb the water that is needed for the germination process. Sodium nitrophenolate is a growth stimulant in plants, but sodium nitrophenolate is not the same as hormone stimulants. Hormones can only stimulate growing parts limited, but sodium nitrophenolate can actively stimulate all plant tissues biochemically and directly seep through roots, stems and leaves so that it can accelerate the plant growth process. According to Effendi (1999) that sodium nitrophenolate is plant growth stimulants containing component of $0.2 \%$ orthonitrophenol sodium, $0.05 \%$ dinitrophenol sodium, Paranitrophenol Sodium $0.3 \%$ and sodium 5-nitroguaiacolate $0.1 \%$. The hormones that exist in plants were very few in number, so it is necessary to add growth regulators, to make the plant grow faster (Purwanto 1999).

Seed germinations are influenced by internal and external factors. Internal factors, such as seeds maturity level, seed size, dormancy period, and the presence of inhibiting fluids (herbicides, sodium nitrophenolate). While external factors are commonly referred to as environmental factors, such as water, temperature, oxygen, light, and media. Technically, germination takes place after the seed coat has broken off and then the living roots will emerge. The time needed for ironwood (E. zwageri) to germinate is 6 to 12 months, but with a special treatment (eg cracking the seed coat or filming the seed coat), the germination process can be shortened starting from the 15th day after the seeds are germinated (PT Kiani Hutani Lestari 2001). Based on that, stimulating E. zwageri germination using sodium nitro-phenolates is important. The purpose of this study was to analyze the comparison the fastest time to breaking Ulin seed dormancy (E. zwageri Teijsm \& Binn) from Bali and East Kalimantan island. These research benefits are expected to be able to provide information and input that can be taken into consideration in providing ironwood seedlings (E. zwageri) through rapid and appropriate seeding.

\section{MATERIALS AND METHODS}

\section{Study area}

The research was conducted in two different provinces in Indonesia, i.e., Bali, and East Kalimantan. The first location was in Agricultural Nursery of East Kutai District (Plant Nursery of East Kutai District), Sangatta, East Kutai, $\left(0^{\circ} 31^{\prime} 60.0\right.$ "N, $\left.117^{\circ} 33^{\prime} 47.0^{\prime \prime} \mathrm{E}\right)$. The location altitude of $300 \mathrm{~m}$ asl, with temperature of $27-35^{\circ} \mathrm{C}$ and an average annual rainfall of $1700-2000 \mathrm{~mm}$, the study was conducted from March to May 2018. The second research location is at the Forestry Plant Breeding Center (BPTH). Bali Nusa Tenggara in Denpasar, Bali, (8 ${ }^{\circ} 43^{\prime} 22.4^{\prime S}, 115^{\circ} 11^{\prime} 20.0^{\prime \prime}$ E), with an altitude of $100 \mathrm{~m}$ asl., Temperature of $26-32^{\circ} \mathrm{C}$ and an average annual rainfall of $1900-2600 \mathrm{~mm}$, the study was conducted from June to August 2018.

\section{Procedures}

The materials used were sodium nitrophenolate, topsoil, E. zwageri seeds, plastic bags for polybags. The research equipment was hand sprayers for watering seeds in the morning and evening, measuring cups to measure the volume of sodium nitrophenolate, hoes to topple topsoil before being put into polybags, oysters (axes, hammers) to break the seed coat lining the E. zwageri fruit, camera for documentation and $3 \times 4$ m nursery beds.

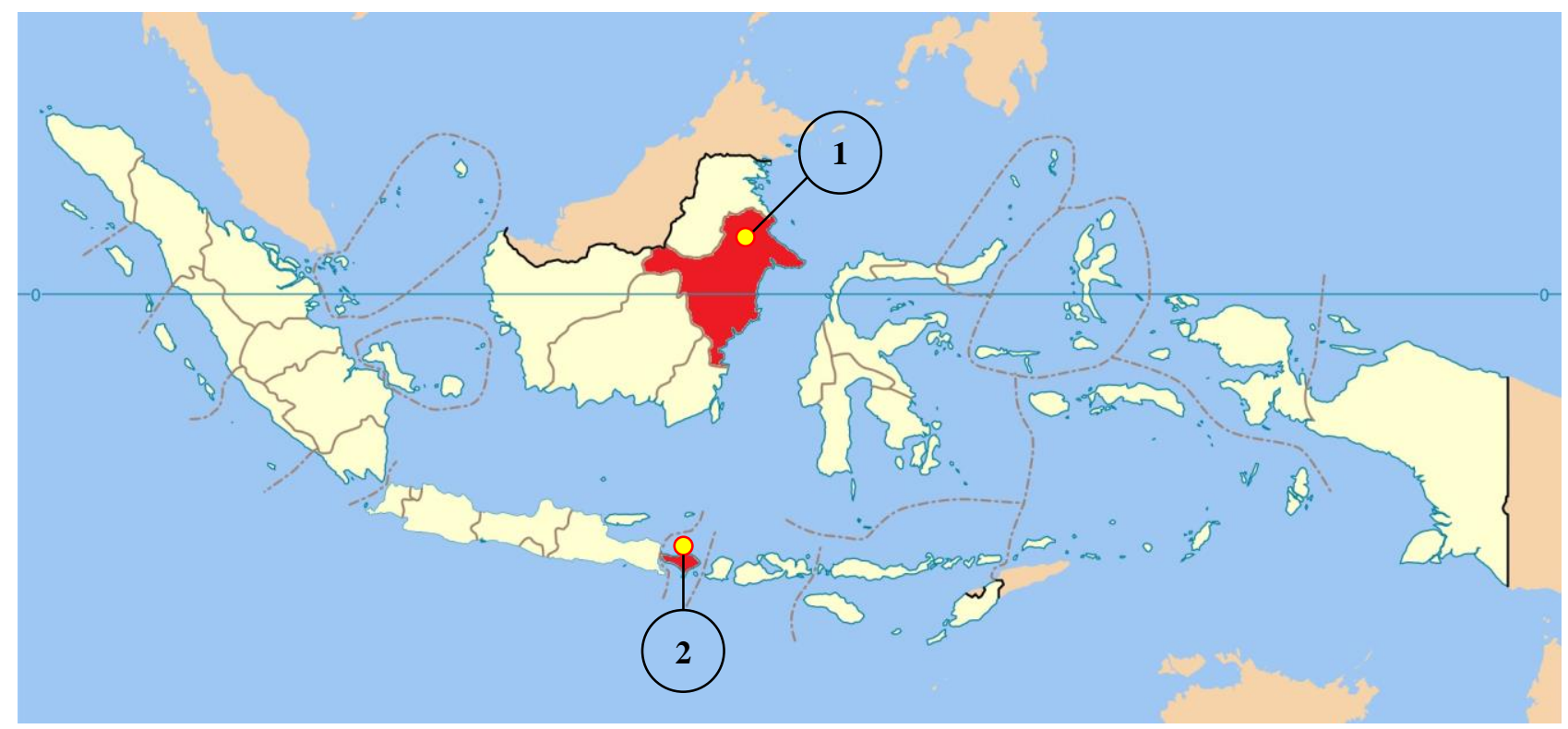

Figure 1. The study sites. 1. Agricultural Nursery of East Kutai District (Plant Nursery of East Kutai District), Sangatta, East Kutai, East Kalimantan, Indonesia. 2. Forestry Plant Breeding Centre (BPTH) Bali Nusa Tenggara in Denpasar, Bali, Indonesia 
In supporting the research referring to Suhardi (1991), that good seeds must have the following things: Sprout power is the power for seeds to germinate in ordinary conditions expressed in the percentage of seeds that germinate in a given time. Germination is commonly termed as the germination percentage (\%). The germination power for each type of seed are varied: (i). Energy germinates, namely the number of seeds that germinate during a certain period, usually shorter than the time used for germination (ii). The germination speed of seeds is the time or day that the seeds need to germinate. This is very important because fast-growing seeds are better able to face sub-optimal fields (iii).

This study was designed in factorial with a randomized block design, using soaking time factor (X) (3 levels) and concentration of sodium nitrophenolate factor (Y) (4 levels). $\mathrm{X}$ factor that is soaking time with 3 treatments: (i) $\mathrm{X} 1=$ immersion (control). (ii) $\mathrm{X} 2=12$ hours soaked time. (iii) $\mathrm{X} 3=24$ hours soaked time. While the $\mathrm{Y}$ factor is the concentration of sodium nitrophenolate with 4 treatments: (i) $\mathrm{Y} 1=$ Without sodium nitrophenolate solution or $0 \mathrm{~mL}$ (control). (ii) $\mathrm{Y} 2=$ Soaked in sodium nitrophenolate solution of $1 \mathrm{~mL} / \mathrm{L}$ of water $(0.1 \%)$. (iii) $\mathrm{Y} 3=$ Soaked in sodium nitrophenolate solution of $2 \mathrm{~mL} / \mathrm{L}$ of water $(0.2 \%)$. (iv) $\mathrm{Y} 4=$ Soaked in sodium nitrophenolate solution of 3 $\mathrm{mL} / \mathrm{L}$ of water $(0.3 \%)$.

Twelve (12) combinations of these two factors were obtained. Each combination was carried out 3 repetitions to obtain 36 experimental units. Each experimental unit was sown 4 E. zwageri seeds. So that the total number of seeds needed in this study is 144 pieces (Gomez and Gomez 1995).

Eusideroxylon zwageri seeds were collected from ironwood trees located in Kutai National Park and North Bontang Region, E. zwageri trees were $35 \mathrm{~cm}$ in diameter, branch free $15 \mathrm{~m}$ and $25 \mathrm{~m}$ tall and straight and cylindrical rods. In general, the size of E. zwageri seeds taken was relatively uniform. E. zwageri seeds that had been collected were cleaned by using water and dried in an open room, after drying the hard seed shells (shells) were broken down so that the embryos or seed meat could be obtained. Furthermore, it was soaked in sodium nitrophenolate according to the soaking time and the solution amount that had been determined into the experimental bath. E. zwageri seeds that had been soaked in sodium nitrophenolate were in accordance with the soaking time and the solution concentration that had been determined, then planted into polybags that had been filled with topsoil. The maintenance of E. zwageri seedlings was carried out to keep the seedling environment clean so it was free from fungal and other disorders, while it was watering twice a day, in the morning and evening.

\section{Data analysis}

Retrieving the first data of the number of seeds germinating is done every day after seeding. The second measurement and so on was carried out every 15 days until 2 months (60 days). Measurements and observations include:

\section{Germination speed (days)}

In determining the germination speed the parameters taken were seed germination days, to calculate germination speed using the formula:

$$
\mathrm{KB}=((\mathrm{n} 1 \mathrm{t} 1+\mathrm{n} 2 \mathrm{t} 2+\cdots+\mathrm{nxtx})) /((\mathrm{n} 1+\mathrm{n} 2+\cdots+\mathrm{nx}))
$$

Where:

$\mathrm{KB}=$ Germination speeds

$\mathrm{nx}=$ The cumulative number of seeds that germinate

$\mathrm{t}=$ Number of germinating days

\section{Germination percentage (\%)}

The germination percentage is the number of all seeds sown divided by the number of seeds germinating in the unit and multiply by one hundred percent. Here is the formula for calculating germination percentages:

$$
\mathrm{P}=((\mathrm{n})) /((\mathrm{N})) \times 100
$$

Where:

$\mathrm{P}=$ Germination Percentage

$\mathrm{n}=$ Number of seeds germinating

$\mathrm{N}=$ Number of all seeds sown (sown)

If the variance results is significant or very significant, then continued with least significant difference test (LSD) with $5 \%$ level.

\section{RESULTS AND DISCUSSION}

\section{Germination speed (days)}

The effect of soaking time and concentration of sodium nitrophenolate plant growth regulator on germination speed is presented in Table 1. E. zwageri seeds in East Kalimantan which germinate the fastest in the treatment of immersion (X1), soaking time 12 hours (X2) and 24 jam (X3) were the seeds soaked in the highest concentration of sodium nitrophenolate $3 \mathrm{~mL} / \mathrm{L}$ (Y4) that were X1 (49.33 days), X2 (47.22 days), and X3 (45.39 days). Also in Bali, E. zwageri seeds which were the fastest germinating in the treatment of immersion (X1), soaking time 12 hours (X2) and 24 hours (X3) were those soaked in the highest concentration of sodium nitrophenolate $3 \mathrm{~mL} / \mathrm{L}$ (Y4), that were at X1 (52.00 days), X2 (49.89 days), and X3 (48.06 days). The germination speed of E. zwageri seeds in Kalimantan was faster than in Bali.

The variance analysis of the effect of sodium nitrophenolate soaking time and concentration on the speed of germination of E. zwageri seeds results were 60 days of seeding soaking time factor $(\mathrm{X})$, sodium nitrophenolate growth factor (Y) showed a very significant effect, while interaction (XY) shows no significant effect on germination speed. The LSD test at the level of $5 \%$ on the soaking time effect $(\mathrm{X})$ using sodium nitrophenolate growth regulators $(\mathrm{Y})$ showed that $\mathrm{X} 1$ (control) treatment was significantly different from X2 (12-hours soaking time) and significantly different from X3 (24-hours soaking time). While treatment X3 (24-hours soaking time) was significantly different from X1 (control) and X2 (12-hours soaking time). 
Table 1. Average germination speed of Eusideroxylon zwageri for each treatment

\begin{tabular}{lcccc}
\hline \multirow{2}{*}{ Treatment } & \multicolumn{2}{c}{ East Kalimantan } & Bali \\
\cline { 2 - 5 } & $\begin{array}{c}\text { Germination } \\
\text { speed (days) }\end{array}$ & $\begin{array}{c}\text { Percentage of } \\
\text { germination }(\boldsymbol{\%})\end{array}$ & $\begin{array}{c}\text { Germination } \\
\text { speed (days) }\end{array}$ & $\begin{array}{c}\text { Percentage of } \\
\text { germination }(\boldsymbol{\%})\end{array}$ \\
\hline X1Y1 & 53.33 & 56.00 & 56.33 & 49.00 \\
X1Y2 & 50.94 & 64.67 & 54.28 & 58.00 \\
X1Y3 & 50.33 & 48.00 & 54.00 & 46.33 \\
X1Y4 & 49.33 & 47.33 & 52.00 & 50.67 \\
X2Y1 & 51.17 & 47.33 & 54.17 & 46.67 \\
X2Y2 & 48.95 & 72.67 & 52.28 & 58.33 \\
X2Y3 & 48.17 & 56.33 & 51.83 & 53.00 \\
X2Y4 & 47.22 & 64.00 & 49.89 & 60.00 \\
X3Y1 & 51.33 & 64.67 & 55.00 & 60.00 \\
X3Y2 & 46.89 & 64.67 & 50.22 & 61.00 \\
X3Y3 & 45.83 & 56.00 & 48.83 & 52.00 \\
X3Y4 & 45.39 & 64.67 & 48.06 & 61.33 \\
\hline
\end{tabular}

Note: X1 (immersion/no soaking time), X2 (12 hours soaked time), X2 (24 hours soaked time), Y1 (No sodium nitrophenolate), Y2 (1 $\mathrm{mL}$ sodium nitrophenolate), Y3 (2 mL sodium nitrophenolate), Y4 (3 mL sodium nitrophenolate)

Table 2. Eusideroxylon zwageri seeds germination speed and germination percentage of based on seed size

\begin{tabular}{lccccc}
\hline \multirow{2}{*}{ Treatment } & Seed size $(\mathbf{c m})$ & \multicolumn{2}{c}{ East Kalimantan } & \multicolumn{2}{c}{ Bali } \\
\cline { 3 - 6 } & & $\begin{array}{c}\text { Germination } \\
\text { speed (days) }\end{array}$ & $\begin{array}{c}\text { Percentage of } \\
\text { germination }(\%)\end{array}$ & $\begin{array}{c}\text { Germination speed } \\
\text { (days) }\end{array}$ & $\begin{array}{c}\text { Percentage of } \\
\text { germination }(\%)\end{array}$ \\
\hline U1 & $10,00-11,00$ & 44 & 25 & 45 & 32 \\
U2 & $11,10-12,00$ & 60 & 50 & 63 & 46 \\
U3 & $12,10-13,00$ & 56 & 60 & 58 & 55 \\
U4 & $13,10-14,00$ & 45 & 80 & 50 & 72 \\
U5 & $14,10-15,00$ & 42 & 70 & 47 & 65 \\
\hline
\end{tabular}

Note: $\mathrm{U}=$ E. zwageri seeds size

\section{Germination percentage $(\%)$}

The effect of soaking time and concentration of sodium nitrophenolate plant growth regulator on percentage of germination is presented in Table 1. E. zwageri seeds in East Kalimantan which were the highest percentage of germination in the treatment of control (X1) was seeds that were soaked in concentration of sodium nitrophenolate 1 $\mathrm{mL} / \mathrm{L}(64.67 \%)$, on soaking time 12 hours (X2) it was soaked in concentration of sodium nitrophenolate $1 \mathrm{~mL} / \mathrm{L}$ (72.67\%), while on 24 jam (X3), percentage of germinations were same in all levels of soaking time exception in $2 \mathrm{~mL} / \mathrm{L}$. In Bali, E. Zwageri seeds which were the highest percentage of germination in $\mathrm{X} 1$ were seeds that were soaked in concentration of sodium nitrophenolate $3 \mathrm{~mL} / \mathrm{L}(50.67 \%)$, while on X2 was Y4 (60.00\%), and on $\mathrm{X} 3$ was Y4 $(61.33 \%)$. The percentage of germination of $E$. zwageri seeds in Kalimantan was higher than in Bali.

The analysis of variance on the effect of soaking time and sodium nitrophenolate concentration on the E. zwageri seeds germination percentage after 60 days of seedling results, showed that soaking treatment, sodium nitrophenolate plant growth regulator concentration and their interaction had no significant effect.

\section{Seed size characteristic}

The effect of seed size on E. zwageri seed germination speed and sprouts percentage is presented in Table 2 . These study results show that $E$. zwageri seeds germination speed in East Kalimantan for seed size treatment was 44 days (U1), 60 days (U2), 56 days (U3), 45 days (U4) and 42 days (U5). While the average $E$. zwageri seeds germination speed was $25 \%$ for (U1), 50\% (U2), 60\% (U3), 80\% (U4) and $70 \%$ (U5). When compared to those in Bali, the average of $E$. zwageri seed germination speed seed size treatment was 45 days (U1), 63 days (U2), 58 days (U3), 50 days (U4) and 47 days (U5). While the average $E$. zwageri seeds germination speed was $32 \%$ (U1), $46 \%$ (U2), $55 \%$ (U3), $72 \%$ (U4) and 65\% (U5).

\section{Discussion}

Ironwood trees (E. zwageri) grow well in lateritic soils that are not covered by old bushes and also grow well on the alluvium soil on the tributaries banks. E. zwageri trees are often found in wet tropical forests with high humidity and temperature with a large number of rainy days. $E$. zwageri trees like soil that absorbs water easily and does not require high soil fertility requirements. This tree can grow well in clay and muddy soils and on steep slopes because hard and large seeds roll down the slope. The $E$. zwageri trees grow in a type A climate according to the Schmidt \& Ferguson category. The E. zwageri trees flowering period occurs once a year, between April and May, the flowering period is generally irregular and the best flowering is in the middle of the year or in the end of the dry season. The E. zwageri tree fruiting period is also irregular, usually between the beginning and middle of the rainy season. Three months after flowering, the E. zwageri 
will mature, it begins with the fruit color change from green to blackish brown. These trees breed with seeds. $E$. zwageri seeds germination is very irregular and sometimes it does not germinate in a year. The mature seeds condition has several chemical compounds, for example, polyphenols, cyclic materials, or lignin, all those chemical compound can accumulate on the seed skin and cause mature seeds to be hydrophobic. The difficulty factor for seeds to germinate is the mature seeds impermeability, it can make a low percentage of seed germination. In addition, the accumulation of endogenous abscisic acid high in mature seeds also inhibits seed germination (Lee et al. 2007; Hsu and Lee 2012; Komara et al. 2016; Setiaji 2018). The E. zwageri trees from seeds difficult to grow, while E. zwageri trees generally form new shoots on the posts of trees that have been cut down or on old E. zwageri trees. E. zwageri trees that are originating from bud are easy to grow if the bud in the large size.

Growth regulators treatment can help to break the $E$. zwageri dormancy. E. zwageri seeds have a hard skin characteristic. Breaking seed dormancy makes the seeds grow faster, because it takes a long time if the seed is breaking naturally. Soaking treatment with sodium nitrophenolate can spur the dormancy time. The average time in East Kalimantan E. zwageri seeds grows in day 45. While the E. zwageri seed dormancy breaking from Bali grows on day 48 average. The germination speed of $E$. zwageri seeds from Bali is slower than that from East Kalimantan because this tree is an endemic tree of Kalimantan island. Giving sodium nitrophenolate substances was helping to break dormancy much faster (in 1.5 months), compared to nature which grow within one year. However, the germination percentage by an average of $58.86 \%$ in Kalimantan and $54.69 \%$ in Bali is still quite low compared to the germination of other plant seeds (Wulandari et al. 2015). The low E. zwageri seeds germination percentage is caused by these plants seed characteristic that has a very hard seed coat that make it difficult to absorb water that is needed for the germination process, which was not solved perfectly by the treatments in this research. The effect of growth regulators grows differently, even among different varieties within a species (Leopold 1963; Siregar and Djaman 2017; Sasmita et al. 2019). When compared with other types of growth regulators treatment, i.e., the use of IBA hormone concentrations and fertilizers to speed up E. zwageri seeds germination, it gives shorter time and more seeds to germinate. The treatment shows that soaking the IBA hormone concentration makes the germination less than one month (Ernayati and Leppe 1992). A research conducted by Hamdansyah (1999) the effect of bright and dark light on the speed of E. zwageri seeds germination which their skin was discarded and placed on sowing beds, was carried out in Samboja. The results showed in dark conditions the speed of germination was faster than bright light conditions. In dark conditions, E. zwageri seeds began to germinate after 28 days, but the sprouts percentage was very small, which was less than $50 \%$.

The study results of Ernayati and Leppe (1992) E. zwageri seeds soaking time between sodium nitrophenolate and soaking time treatment using IBA hormone concentration of 0.5-1.5 tablets/liter of water, the results showed that soaking treatment with IBA hormone was giving a higher germination percentage, which was more than $80 \%$. High germination energy of $82 \%$ was obtained from 1 tablet/liter of IBA treatment. In another study conducted by the Samarinda Forestry Research and Development Center, the E. zwageri seeds storing method carried out in a greenhouse. The E. zwageri fruit treatment included seed selection washing with Chlorox and distilled water solution. The E. zwageri stored in a bucket which given holes, without holes, placed in room temperature and air-conditioned rooms. The results showed that the seeds stored in a bucket with a hole produced a higher percentage of germination than a bucket without holes. The best $E$. zwageri seeds storing temperature was sowing in the 24$33^{\circ} \mathrm{C}$ room temperature (Ernayati and Nina 1994; Sidiyasa and Juliaty 2001).

From the study results, it was found that the appropriate soaking time plays an important role in the E. zwageri seeds germination process. This can be seen by the high germination percentage and germination speed of $E$. zwageri seeds that soaked in sodium nitrophenolate for 24 hours. Sodium nitrophenolate contains nitro-organic compounds that stimulate physiological and metabolic processes that make nutrients in plants and uptake results can be used optimally and balanced (Hartutiningsih et al. 2005). Water is one of the factors needed in the initial growth in addition to the treatment of E. zwageri hard seeds stripping, this is helpful in the germination process. The factors that determine the growth speed are nutrients, water content, and light. Nutrients and water are needed for the plant bodies formation, while air, $\mathrm{CO}_{2}$, and water with the help of light produce carbohydrates which are a source of energy to grow. According to Kamil (1979), water functions is to provide oxygen entry into the seeds, destroys the protoplasm so that it can activate various functions and as solvents and transport food solutions from endoplasm or cotyledons to the growth point.

The variance results showed that the sodium nitrophenolate factor had no significant effect on the percentage of germination and gave a very significant effect on germination the speed. The sodium nitrophenolate solution is a nitroaromatic or sodium vinyl compounds which have the power to stimulate growth in plants. If the sodium nitrophenolate is given in the right concentration, it can accelerate the rate of germination or seed growth. Furthermore, according to Dwidjoseputro (1986), that's the substances of growth regulator can increase seed germination power if it is given correctly and will spur the cell division process. Sodium nitrophenolate is a growthregulating agent that has functions to stimulate root growth, activate nutrient absorption, increase flower buds, fruits and improve the quality of crops. The sodium nitrophenolate form is a concentrated solution and free of toxins so it is not harmful to humans and animals. Sodium nitrophenolate can actively stimulate all tissues to grow biochemically and directly seep into plant tissues so that it will accelerate seed metabolism. Sodium nitrophenolate contains the active ingredient of nitroaromatic compounds. 
This compound stimulates seeds and plants. Phenol compounds include the compounds that derived from plants with the same characteristics, namely aromatic rings containing one or two hydroxyls. Phenol compounds tend to dissolve easily in water, the phenol role includes cell walls building. The growth regulators effectiveness in plants is influenced by the concentration given, because concentration differences will cause activity differences (Nurlaeni and Surya 2015).

Seed size affects the E. zwageri seeds germination greatly (Table 2). A large E. zwageri seeds tend to germinate faster than a small one. Treatment of seed size differences can determine the difference in dormancy time. The average of E. zwageri seeds from East Kalimantan grows well on the $42^{\text {nd }}$ day with $14 \mathrm{~cm}$ seed size. While the breaking of $E$. zwageri seed dormancy from Bali based on its size grows on the $45^{\text {th }}$ day with $10 \mathrm{~cm}$ size. E. zwageri seeds from Bali were slower than seeds from East Kalimantan, because this tree is an endemic tree of the Kalimantan Island. However, a smaller seeds average size is growing faster in Bali island. Similarly, the germination percentage is more moderate. The germination percentage is quite good $65-70 \%$ due to a large amount of food reserves contained in E. zwageri seeds compared to smaller ones, so that the ingredients contained in E. zwageri seeds are used to stimulate the seed. Another study was conducted by Yusliansyah et al. (2004), E. zwageri seeding by filing the seed shell and breaking it down, can grow within 15 days and the sprouts percentage was $70 \%$. While it can reach three months without treatment and a very low sprouts percentage. The success rate until the seeds are ready for planting is between $30-55 \%$ from natural stand, $70-80 \%$ for $E$. zwageri seeds with treatment and $25-30 \%$ from cuttings from E. zwageri buds. E. zwageri seed germination conducted by PT Kiani Lestari (2001) with various treatments on seeds ranged from 70-80\%. Large seeds tend to germinate faster than small one. Similarly, the germination percentage is greater. High germination and germination percentage are thought due to the large food reserves contained in E. zwageri seeds which will be larger than smaller ones, so that the ingredients contained in $E$. zwageri seeds will be used to stimulate germination. Breaking dormancy with growth regulators will increase plant growth, shoot growth into flowers, while the seedlings size will increase the number of seedlings simultaneous to shoot with good plant vigor (Adi et al. 2015).

Naturally, the level of E. zwageri seedlings is below the parent tree canopy projection, while at the sapling level it was less. According to Rusdiana (1998) and Ardiyansyah (1991), the highest seedling level found, i.e., in the 0.6$0.7 \mathrm{~cm}$ diameter class. The number of seedlings per parent tree is 270 tillers with a density of 0.3-0.4 individuals per square meter. Average natural regeneration in Kutai National Park, Protected Forests of Sungai Wain and Gunung Meratus range from 60-168 tillers per tree. The distance of seedling spread from the parent tree is 1-15 meters. The distribution area for one parent tree can reach 0.15 hectares. In some different slope areas, the farthest spread of the seeds from the parent tree according to the back area, slopes, and valleys are 12,14 and 10 meters respectively. The closest spacing of seeds from the mother tree to the back, slopes, and valleys is 2, 1 and 1 meter, respectively. The farthest distance of the seedlings spread from the mother tree on the back, slopes, and valleys is 15 , 11 and 12 meters respectively. The closest spreading distance of seedlings from the mother tree to the back area, slopes and valleys is 2, 1 and 1 meter respectively. In the back, slope, and valley areas, the relative values of seedling average increment are $14.52 \%, 15 \%$, and $18.10 \%$, respectively. The mean relative values of seedling height in the back, slope, and valley areas were $7.70 \%, 6.78 \%$, and $9.52 \%$ respectively.

Eusideroxylon zwageri population in natural forests has been dwindling due to continuous exploitation. If this condition is not anticipated earlier, its presence will continue to decrease, while the information on cultivation techniques (silviculture) from nursery to planting is widely unknown. In order to support the effort of developing and conserving E. zwageri plants, information and studies on appropriate and efficient cultivation techniques are needed, which are fitted with the plants characteristics and their growth places. From the earlier study results research, it appears that by using good quality seeds will save costs in nurseries (Sofyan and Laksono 2001). Seeds are produced directly in one stage without weaning, from one seed can be used into two or three seeds, thus the use of media will also be more efficient and efficient.

In conclusion, the best treatment for the E. zwageri seeds germination speed is at 24 hours soaking time by giving $3 \mathrm{~mL}$ of sodium nitrophenolate concentration. Based on the LSD test 5\% level, the sodium nitrophenolate immersion soaked time and concentration showed a very significant effect, while the interactions of both showed no significant effect. The best germination percentage is in the 12 hours soaking times by giving $1 \mathrm{~mL}$ of sodium nitrophenolate concentration. The soaking time, sodium nitrophenolate concentration and the interaction of both showed no significant effect on the germination percentage. The breaking of E. zwageri seed dormancy from Kalimantan has a shorter time and the growth percentage is better compared with E. zwageri seeds from Bali. Further research is needed with the same growth regulator substances with different concentrations and in longer soaking time, it is expected to get better, faster and more appropriate germination results.

\section{ACKNOWLEDGEMENTS}

This search was funded by the Directorate General for Higher Education of Republic Indonesia granted to the first author. Many thanks to the Ministry of Forestry, Forest Plant Breeding Center (BPTH) Bali-Nusa Tenggara at Denpasar, Indonesia.

\section{REFERENCES}

Adi EBM, Indrayani S, Mulyaningsih ES. 2015. Breaking ginger dormancy with the application of NAA and BAP growth regulatory 
substances. Proceeding of National Seminary of Society for Indonesian Biodiversity 1 (1): 105-108. [Indonesian]

Ardiyansyah. 1991. Distribution of ulin seeds and seedlings (Eusideroxylon zwageri) from the main tree and growth in different forms of physiography. Samarinda. [Indonesian]

Dwidjoseputro D. 1986. Introduction to Plant Physiology. PT Gramedia. Jakarta. [Indonesian]

Effendi R. 1999. Study of planting shoot cuttings of ulin (Eusideroxylon zwageri) using atonic hormone concentration. Faculty of Forestry, Mulawarman University. Samarinda. [Indonesian]

Ernayati, Leppe D. 1992. Effect of IBA Hormones and Three Types of Fertilizers on Ulin Tiller Growth. Forestry Research Center. Samarinda. [Indonesian]

Ernayati, Nina J.1994. Teknik seleksi dan penyimpanan benih ulin (E. zwageri $T$. et B.), rotan sega (C. caesius Blume) dan ramin (Gonystilus spp.). Laporan Tahunan Balai Penelitian Kehutanan Samarinda. (Not publish) [Indonesian]

Gomez KA, Gomez AA. 1995. Statistic Procedure for Agricultural Research. 2nd ed. UI Press. Jakarta.

Hamdansyah. 1999. Effect of light on ulin Germination (Eusideroxylon zwageri). For Res Bull 13 (2):21-26. [Indonesian]

Hartutiningsih M, Siregar IP, Suendra, Siregar M. 2005. Rosa $x$ odorata "viridiflora" (green rose) in Bali Botanical Garden: Biological phenology and its propagation. Biodiversitas 6 (3): 181-184.

Hsu RCC, Lee YI. 2012. Seed development of Cypripedium debile Rchb.f. in relation to asymbiotic germination. Hort Sci 47 (10): 14951498.

Kamil J. 1979. Seed Technology. Angkasa Raya. Padang. [Indonesian]

Kelian BR. 1993. Pengamatan skarifikasi perkecambahan biji ulin (Eusideroxylon zwageri) secara mekanis. PT. KEM, Kutai Barat [Indonesian]

Komara LL, Choesin DN, Syamsudin TS. 2016. Plant diversity after 16 years post coal mining in East Kalimantan, Indonesia. Biodiversitas 17: 531-538

Lee YI, Lu CF, Chung MC, Yeung EC, Lee N. 2007. Developmental changes in endogenous abscisic acid concentrations and asymbiotic seed germination of a terrestrial orchid, Calanthe tricarinata Lindl. J Amer Soc Hort Sci 132: 246-252.

Leopold AC. 1963. Auxin and Plant Growth. University of California Press, Berkeley, CA.

Mackinon K. 2005. Parks, People and Policies: Conflicting Agendas for Forest in Southeast Asia 558-582. Tropical Rain Forest. The University of Chicago press.
Martawijaya A, Kartasujana I, Madang YI, Prawira SA, Kadir K. 1989. Indonesian Wood Atlas Volume II. Forestry Research and Development Agency. Jakarta. [Indonesian]

Nurlaeni Y, Surya MI. 2015. Response of Camelia japonica shoot cuttings to the treatment of organic growth regulating substances. Prosiding Seminar Nasional Biodiversitas Indonesia 1: 1211-1215. [Indonesian]

PT Kiani Hutani Lestari. 2001. Experience in the cultivation of ironwood plants (Eusideroxylon zwageri). Jakarta. [Indonesian]

Purwanto. 1999. Agarwood producing cultivation. Main Papers in Expose of Research Results. Pematang Siantar Forestry Research Institute. Field. [Indonesian]

Rusdiana. 1998. Natural regeneration of ironwood species (Eusideroxylon zwageri) in different slopes of Lempake primary forest. Faculty of Forestry, Mulawarman University, Samarinda. [Indonesian]

Sasmita N, Purba JH, Yuniti IGAD. 2019. Adaptation of Morus alba and Morus cathayana plants in different climate and environment conditions in Indonesia. Biodiversity 20: 544-554

Setiaji A, Setiari N, Semiarti E. 2018. Induction of shoots from intact protocorms and early stages of development of Dendrobium phalaenopsis in vitro. Prosiding Seminar Nasional Masyarakat Biodiversitas Indonesia 4: 20-27. [Indonesian]

Sidiyasa K, Nina Juliaty. 2001. Preservation of ironwood trees (Eusideroxylon zwageri), aspects of utilization, cultivation and conservation. Paper at the Workshop on Preservation of Endangered Flora Species (Ulin), Bapedalda, East Kalimantan Province. [Indonesian]

Siregar N, Djam'an F. 2017.The effect of plant material on the success of cutting of kranji (Pongamia pinnata). Proceeding of Indigenous Biodiversity 1 (3): 23-27. [Indonesian]

Sofyan A, Laksono B. 2001. Ulin nursery techniques (Eusideroxylon zwageri Teijsm \& Binn). Proceedings of the Palembang BTR Research Results 5-11. [Indonesian]

Suhardi. 1991. Planting Basics. Kanisius Publisher. Yogyakarta. [Indonesian]

Wulandari W, Bintoro A, Duryat. 2015. The effect of seed size on seed germination of mirabow (Intsia palembanica). Jurnal Sylva Lestari 3 (2): 79-88. [Indonesian]

Yusliansyah, Ngatiman, Sukanda, Ernayati, Wahyuni T, Effendi R. 2004. Research and Development Status of Ironwood (Eusideroxylon zwageri Teijsm \& Binn). Kalimantan Forestry Research and Development Center, Samarinda. [Indonesian] 